\title{
Zoja Bojić
}

The Institute for the Literature

and the Arts, Belgrade

ZojaBojic@hotmail.com

ORCID: 0000-0002-2721-803X

\section{The Slav Avant-garde in Australian Art}

Abstract: Bojić Zoja, The Slav Avant-garde in Australian Art. "Poznańskie Studia Slawistyczne" 18. Poznań 2020. Publishing House of the Poznań Society for the Advancement of the Arts and Sciences, Adam Mickiewicz University, pp. 37-48. ISSN 2084-3011.

Australian art history includes a peculiar short period during which the European avant-garde values were brought to Australia by a group of Slav artists who gathered in Adelaide in 1950. They were brothers Voitre (1919-1999) and Dušan Marek (1926-1993) from Bohemia, Władysław (1918-1999) and Ludwik Dutkiewicz (1921-2008) from Poland, and Stanislaus (Stanislav, Stan) Rapotec (1911-1997) from Yugoslavia, later joined by Joseph Stanislaus Ostoja-Kotkowski (1922-1994) from Poland. Each of these artists went on to leave their individual mark on the overall Australian art practice. This brief moment of the artists' working and exhibiting together also enriched their later individual work with the very idea of a common Slav cultural memory.

KEYwords: Slav cultural memory; Slav artists; émigré artists; avant-garde; Australia

The news of Dada reached Australian shores late, but not later then immediately after the Second World War together with the news of surrealism. Two events facilitated the spread of the Dada ideas in Australia. One was an interest by several Melbourne based writers and, to a lesser degree, visual artists, in the avant-garde practices of pre-Second World War Europe as articulated by the modernist magazine Angry Penguins published firstly (1940) in Adelaide, South Australia then after 1942 in Melbourne, Victoria, until 1946. The other was the post-Second World War migration which included the arrival of several young and well informed European émigré artists of Slav origins to Australia, initially to South Australia.

The Angry Penguins magazine was founded by a young avant-garde Australian poet Max Harris, derived its name from a line of his absurdist poem Mithridatum of Despair, and championed the experimental, irrational and modernist poetry and arts. The Melbourne modernist arts 
scene in 1945 included a group of young artists of the Heide Circle such as Albert Tucker (1914-1999), Joy Hester (1920-1960) and Sidney Nolan (1917-1992) whose work at the time was strongly inspired by the Russian-Australian expressionist painter Danila Vassilieff (1897-1958). These artists' contributions to the Angry Penguins combined their interest in expressionism with their interest in the European anti-war and anti-violence First World War avant-garde which resonated with the Australian urban culture at the time of the Second World War. They provided the Angry Penguins with several paintings such as Albert Tucker's cover for the December 1945 issue, a chaotic composition of forms, objects and symbols which resembled the Dada collage and photomontage imagery representing wartime horror. The last issue of the Angry Penguins dated as Autumn 1944 featured the cover page by Sidney Nolan, again a painting executed as an illustration to the lines of an absurdist poem by the fictitious poet Ern Malley.

The arrival of the two pairs of brothers, Voitre (1919-1999) and Dušan Marek (1926-1993) from Bohemia, and Władysław (1918-1999) and Ludwik Dutkiewicz (1921-2008) from Poland, as well as several other artists of Slav origins such as Joseph Stanislaus Ostoja-Kotkowski (1922-1994) from Poland and Stanislaus (Stanislav, Stan) Rapotec (1911-1997) from Yugoslavia just before 1950, and initially to South Australia, injected Australian art with the European art practices, ideas and different viewpoints. Although these artists, who all experienced the horrors of the Second World War first hand, would soon undertake each their own path and would leave a mark in several other aspects of Australian art practice over the next half a century, their short common sojourn in South Australia resulted in staging of several theatrical performances, exhibitions with the Contemporary Art Society and outside of it and film-making experiments characterised by their common interest in the surreal, non-logical and non-sequential.

At different times the construct of the avant-garde indicated different trailblazing movements. In the history of the visual arts, the avant-garde can also be seen as an evolving quality. The supple and self-adjusting nature of an avant-garde and its modification into a new and different avant-garde can perhaps best be seen on the example of several practices in the twentieth century art in Australia. Dada and surrealism were the avant-garde introduced to the Australian visual arts practice in 1950 by a group of Slav artists, and 
observing their work taking new shapes towards abstraction and championing it can be seen as one example of this trend. For these artists, who all worked individually, abstraction, especially gestural expression, was simply a continuation of their previous Dada and surrealist interests. Gestural and abstract painting are usually considered as the modes of expression of American artists almost simultaneous to the French art informel. When this is put in a context of Australia's comparative isolation, a different picture emerges. A small group of artists of Slav origins who all, in difficult times yet nevertheless in search of an adventure ended in Australia after the Second World War, developed these very ideas of gestural abstraction as a natural and logical evolution of ideas of Dada and surrealism which they brought to the far and very foreign shores. ${ }^{1}$ In their continuous art practice, they did not dwell on the memory of an avant-garde but continued to champion its new varieties. This is in contrast to the characteristics of the oeuvre of some of the most prominent Australian surrealists such as the painter James Gleeson (1915-2008) (Klepac, Wach, Free, James 2004) and the sculptor Robert Klippel (1920-2001) (Edwards, 2002) whose idioms, although highly developed through their art practices, stayed true to the art expression they each acquired overseas in the late 1940s. This is also in contrast to the extraordinary oeuvre of the Australian painter John Olsen (born 1928) who fully developed his abstract expressionistic idiom upon his return to Australia from Europe in 1960 (Bungey, 2014).

It is possible to identify some of the earlier works by the Adelaide cluster of Slav artists as those strongly referencing their migration experiences of which many were literally surreal. One such example is the painting $G i$ braltar from 1948 by Dušan Marek, executed on board of a ship docked for several months during its long and complex journey to Australia, another painting, Equator also by Dušan Marek from 1948, representing a memento of the ship crossing to the Southern hemisphere, the meaning of which was lost on the audience deprived of such an experience (Casey, 2018). Among the artworks which Marek brought to Australia were his The Voyage and the Birth of Love, both dated in 1948.

${ }^{1}$ This idea was first voiced out in the content as well as the title of Adam Dutkiewicz's (2000) PhD thesis: Raising Ghosts: Post-World War Two European Emigré and Migrant Artists and the Evolution of Abstract Painting in Australia, with Special Reference to Adelaide ca.1950-1965. 
Several catalogues of the exhibitions staged in Australia over the past few decades presented works by artists who migrated to Australia immediately after the Second World War. One such example is the showing of From migrant to citizen: artistic accents at the Macquarie University in Sydney in 2008 and 2009 (Hammond, Menadier, 2008). Although these artists had a migration experience in common, their work rarely contained the imagery of their deeply troubled voyages, initial hardship and nostalgia upon arriving. In contrast, the works by the Adelaide cluster of Slav émigré artists shows a strong common link. This invokes the question: are there any Slav peculiarities within these idioms? It is not possible to argue for the existence of Italian, French, German or even British cultural memory evident in Australian art. It is, however, possible to argue for the existence of Aboriginal art as an entity, as diverse as this art practice can be, on the grounds of a common cultural memory evident in this art practice. It is similarly possible to argue for the existence of a common cultural memory evident in the works of Slav émigré artists in Australia (Bojic, 2005).

All of the Slav émigré artists of the Adelaide cluster were well versed in the history of the avant-garde in the European art, poetry and philosophy. All of them, each in their unique manner, drew on their cultural memory, and in doing so created vastly different new individual idioms often imbued with a broader Slav cultural memory. Many works by these artists carry the construct of Slav cultural memory even in their titles, such as Rapotec's later work King Matijas from 1981 or Voitre Marek's early work Golden hen from 1948. Unintentionally, in this they continued the practice established by another Slav émigré artist in Australia of a previous generation, the Russianborn figurative expressionist Danila Vassilieff. His works bore titles such as The Firebird from Drummoyne, from 1944, Gnome from 1950, Flying Horse from 1951 and Stenka Razin from 1953, to name just a few.

Vassilieff is considered the father of Australian modernism (Bojic, 2007b). After having experienced first-hand the Russian revolution and having taken several years to escape its aftermath Vassilieff first arrived in Australia, via Shanghai, in 1923. In 1929 he left first to Paris then to Rio de Janeiro where in 1930 and 1931 he studied painting from the traditional icon-painter Dimitri Ismailovitch and started exhibiting his highly modernist works from 1932. By 1935 he travelled and exhibited his paintings in the West Indies, South America, England, Spain and Portugal. 
In 1935 Vassilieff returned to Australia, first settling in Sydney where he dedicated himself solely to painting and began exhibiting with Macquarie Galleries. Two years later he moved to Melbourne where began working as an art teacher, joined the Contemporary Art Society and met a group of artists and intellectuals who formed the Heide Circle. Vassilieff's oeuvre, largely inspired by his cultural memory, includes paintings and sculpture each executed seemingly in a single breath. His early Melbourne works thematically focused on street scenes in industrial city suburbs depicting everyday events, encounters and observations. They often carried visual references to the Russian fantasy stories or heroic and legendary history.

In the period 1936-1940 Colonel de Basil's Russian Ballet ensemble held over six hundred performances across Australia's major cities and Vassilieff's experiencing the ensemble's artistic rendition of Russian and other myths inspired a new body of his works in the early 1940s. It now included his expressionistically rendered personalised Russian Ballet theatre experiences, as well as representations of characters from the artist's personal and cultural mythology such as The Firebird or Peter and the Wolf. During the Second World War Vassilieff's oeuvre also included works inspired by the battles on the Russian soil such as Stalingrad from 1945. He began making stone sculpture and until mid-1950s created many such works among which perhaps the most prominent were beforementioned Gnome, Flying horse and Stenka Razin. From 1954 to 1957 Vassilieff taught art in far flung places in the state of Victoria where his fast, colourful, witty and even grotesque paintings reflected his encounters with the characters and the mentality of small towns. He exhibited at the Gallery of Contemporary Art in Melbourne in 1956 and in 1957 to adverse critique. Vassilieff died of heart failure in 1958. Today his works are held in major public galleries in Australia.

Vassilieff's expressionistic style, and his insertion of the elements of his cultural memory into his subject matter attracted several young Melbourne artists such as Albert Tucker, Joy Hester and Sidney Nolan and strongly influenced their work (Haese, 1981). Their short involvement with the Angry Penguins in 1944 and 1945 is just a little testament to this. Nolan's further oeuvre was based on Vassilieff's idea of retelling through his art the basic notions of his own cultural memory and the character of Ned Kelly, an Australian outlaw and police murderer, continually appeared 
as central to his art practice (Pearce, 2007). Tucker's work at the time was based on Vassilieff's philosophical concept of the perennial battle of forces of good against evil which Tucker employed in his Images of Modern Evil and further developed in his apocalyptic imagery (Burke, 2002). Hester's oeuvre was focused on the artist's emotional intensity (Burke, 1983) introduced by Vassilieff's unique expressionistic idiom.

\section{The Adelaide cluster}

\section{The Adelaide Dada avant-garde}

The brothers Dušan and Voitre (Vojtech) Marek (Mould, 2008) were born in Bohemia and studied art in Prague, Voitre under Professor Jaroslav Horejc and Dušan under the surrealist František Tichý, and Voitre established a studio there. In 1948, the brothers embarked aboard the Charleton Sovereign sailing for Australia, landed in Sydney, were sent to Bathurst migrant camp, then settled in Adelaide where they first worked at a jewellery firm as engravers. Over the initial two years in Adelaide the Marek brothers exhibited their paintings in group exhibitions sometimes to a controversial reception. ${ }^{2}$

In 1951, Dušan moved first to Tasmania, then Sydney where in 1953 he exhibited in a controversial show at the Mack Gallery, prompting him to leave for Papua New Guinea, until 1959. He turned to film-making and produced a film while there, then returned to Adelaide, continued with the experimental film-making and created a series of abstract surrealist landscape paintings which in 1963 he exhibited at the Bonython Gallery, Adelaide. He returned to Sydney the same year and produced another surrealist movie, then in 1969 returned again to Adelaide to produce another surrealist feature-length film and a series of paintings. During the 1970s, Dušan was invited to take post of a professor of painting and film studies at the Tasmanian School of Art in 1975, he held a solo exhibition at the Art Gallery of New South Wales in Sydney in 1975, took a fellowship at the

${ }^{2}$ Dušan's work Equator was infamously rejected from the Contemporary Art Society exhibition in 1949 and later shown in the Adelaide Independent Group exhibition. 
Australian National University in Canberra in 1979, and travelled in the USA and Europe. He finally settled in Adelaide and in 1980s produced a series of paintings Homage to the Sun and the Eye of the Heart. He died in 1993 just the night prior to the opening of the exhibition Surrealism: Revolution by Night displaying some of his work at the National Gallery of Australia.

Voitre settled in Adelaide and until 1960 his art practice largely consisted of surrealistic and abstract drawings and prints which he showed in a solo exhibition at the Royal South Australian Society of Arts in Adelaide. In the 1960s, however, his interest turned towards religious art much of which he created for many churches across Australia. In 1966, Voitre had a solo show at the Adelaide Festival and in the late 1960s was awarded the Churchill Fellowship for the studies in religious art. He died in 1999.

\section{The Adelaide Abstraction avant-garde}

The Dutkiewicz brothers, Władysław and Ludwik were born near Lwow and after studying in Europe and time spent in Bavaria in the aftermath of the war, migrated to Australia in 1949, settling in Adelaide. Władysław attended art classes at the Academy of Fine Arts in Krakow and the École des Beaux-Arts in Paris, and theatre classes at the Great Theatre in Lwow. He arrived in Adelaide as an accomplished professional sculptor, draughtsman, painter and theatre designer who worked incessantly, exhibited profusely, ran several theatre companies and was involved in experimental film-making. Since his early days in Adelaide, Władysław’s visual arts practice in Australia could best be described as abstract, as Adam Dutkiewicz $(2006,25)$ writes:

From my research into his art it is clear that initially he was not too experimental: the paintings he managed to execute in Bavaria after the war were solid yet quite tame exercises in landscape, still-life and portraiture, in which he searched to find his "voice." They were produced in a well-crafted, rather academic style, but showed flair with brushwork and a finely tuned sensibility and flair for expression and abstraction.

His early painting in Australia, however, indicates an amazing and torrential outpouring of pent-up creative energy. Wlad's first solo exhibition was at Curzon Gallery in early June 1951. The work caused a sensation among the circles of artists and exhibition-goers. During his first solo shows at the Royal South Australian Society of Arts patrons 
were seen queuing up the stairs and outside of the Institute Building on North Terrace waiting for the gallery to open. The debate about radical modernism in Adelaide was reignited well before the French Painting Today touring exhibition in 1953, an event often highlighted as a turning point in Australian art, as it heralded the rise of abstract painting, which Wlad regarded as an art of limitless possibilities.

The same author goes on to say that "in the 1950s and '60s he was widely regarded as a leader of the lively modern art movement in Adelaide." In the 1960s

Wlad produced drawings and paintings on an earlier theme, his contact with Aborigines in Western Australia in 1949, and depicted in his highly personalised style the touring Bolshoi and Mazowsze ballet companies, his own theatre group and the parties, the street performers in the Festival, the Russian circus and the Adelaide Christmas Pageant. He also painted fleeting moments in life that he was able to somehow photograph in his mind and develop into superbly coloured and textured, poetic encapsulations of experience (Dutkiewicz, 2006, 27).

Ludwik Dutkiewicz similarly to his brother arrived in Australia as an expressionist painter and soon upon arriving became an abstractionist. After having completed his studies at the Lwow Polytechnic he spent several years in the post-war Bavaria prior to reaching Adelaide where in 1951 together with Władysław he exhibited at the Royal South Australian Society of Arts and became a prominent member of the Contemporary Art Society. Since 1953 he worked as a botanical illustrator for the Botanic Gardens, and continued his professional visual arts practice and theatre production work. Since 1964, Ludwik began working on experimental film-making.

Another Polish artist who made a significant mark on the Adelaide arts scene, was Joseph Stanislaus Ostoja-Kotkowski, born in Golub, studied drawing in Przasnysz and then at the Düsseldorf Academy of Fine Arts in Germany in 1949. He migrated to Melbourne in 1950 and studied at the Victorian School of Fine Arts National Gallery School until 1955 when he moved to a place near Adelaide. His painterly art practice was focused on geometric abstraction. However, his best known works belong to the field of photography, experimental film-making, design, and laser kinetics and sound and image production which set the ground for contemporary experimental computer generated imagery and sound production (Davidson, 1999). Ostoja-Kotkowski's art practice became removed from the field of the purely visual arts venturing into the high-tech experimental sound and 
image design of which he was one of the pioneers in Australia and further afield.

\section{Abstraction as avant-garde}

The question of abstraction (expressionistic or geometric) as avant-garde can be observed within the context of the history of Australian art. Some of the earliest examples of abstraction in Australia are those by Roy De Maistre (1894-1968). Inspired by the European artists he devised a "colour-music" theory where a colour corresponded to a sound. With Ronald Wakelin he held the exhibition Colour in Art, the first abstract art show in Australia, in 1919. In the 1930s, De Maistre's art practice turned figurative. The next generation of Australian abstractionists are those linked to the Andre Lhote Parisian school from where they brought cubism inspired ideas in the 1920s and 1930s. Among them was Grace Crowley (1890-1979) who introduced the Sydney audiences and the students of her own school to geometric abstraction. Her fellow artists included Rah Fizelle, Ralph Balson and Frank Hinder who exhibited together as a group at the Exhibition 1 at the David Jones Gallery in Sydney in 1939 and dispersed after the Second World War. Both Crowley and Balson continued to show their abstract works. These forms of abstraction can be seen in parallel to the work by Ian Fairweather (1891-1974), a reclusive artist residing in Australia on and off for extended periods of time. Fairweather created a major body of work which can be labelled as a blend of figurative and abstract expressionism, with his visual language including influences of Indigenous art and the arts of several cultures of Asia.

However, abstract expressionism in Australia is usually equated with the work of the Sydney 9 group (Heathcote, 1995) who exhibited together in 1961: Hector Gilliland, Leonard Hessing, the sculptor Clement Meadmore, John Olsen, Carl Plate, Stanislaus Rapotec, William Rose, Eric Smith and Peter Upward.

In 1956 a group exhibition of Australian non-figurative artists Direction I was held in Sydney. In 1959 the Antipodeans, a group of figurative artists mostly based in Melbourne lead by the art historian Bernard Smith, feeling the need to defend the image against abstraction participated in a single 
exhibition, which was accompanied with the Antipodean Manifesto. In response, the eclectic Sydney 9 group exhibited together in both Sydney and Melbourne and continued with their individual abstract art practice over the next two decades. Here the work of Stanislaus Rapotec (1911-1997), a post-Second World War émigré painter from Yugoslavia, initially to Adelaide, stands out as it is imbued with the artist's personal feelings, affects and experiences. It is possible to argue that the Sydney 9 group and the then rampant gestural abstract expressionism of the 1950s and the 1960s were based, among other factors, on the work of Rapotec (Bojic, 2007a).

Rapotec was born in Trieste, spent his childhood in Ljubljana and youth in Zagreb, Belgrade and Split where he attended art classes. During the war, he fought for the Yugoslav government in exile in covert operations and after the war decided to migrate to Australia. He first settled in Adelaide where he encountered the cluster of Slav émigré artists and started to paint again. Rapotec exhibited together with the Marek and Dutkiewicz brothers and became active on the Adelaide arts scene. In 1955 he permanently settled in Sydney, started exhibiting there, and became one of the best known Australian abstract artists, especially after controversially winning the Blake Prize for a religious painting in 1961. He travelled to Europe on several occasions, exhibiting the new works there and upon his returns to Sydney, such as his series of cathedrals. His works, often referencing his Slav cultural memory, are today held in major public and private art collections in Australia and abroad.

Rapotec's art practice since the late 1950s was very well received by the critics across Australia as he regularly exhibited in Sydney as well as in other major cities in different states. This is in contrast to the overall reception of the abstract works of the other from the original Adelaide cluster of Slav émigré artists. In the words of Adam Dutkiewicz (2006, 30):

It is a pity that the rest of Australia has not appreciated my father's [Władysław Dutkiewicz's] art as much as many people have in Adelaide, until recent decades. I know he was grateful for the friendships and encouragement he received here from many of his colleagues and patrons. There were barriers in the Anglocentric culture of the southern capital, but they were not as great as he found in the eastern states' cities.

Despite the fact that abstraction was not unknown in Australian art since the 1920s, the avant-garde and trailblazing quality of abstraction was 
born only in the early 1950s, both internationally and in Australia. The revolutionary international aspects of abstraction sipped through to Australia via Australian artists returning home from travelling overseas as well as via several exhibitions of foreign art staged in Australia such as the French Painting Today touring exhibition in 1953 which introduced the art informel. The revolutionary and avant-garde quality of the abstract works of the Slav artists forming the Adelaide cluster in 1950 was, on the other hand, although naturally based on their European art experiences, formed in Australia. The Marek brothers' Dada and surrealist paintings obtained the abstract quality on the Australian soil, the very idiom to which both the Dutkiewicz brothers as well as Rapotec also turned to only upon arriving in Adelaide.

The old adage of Australian art history that rings true for many artists of previous generations coming from Britain is that the bright light of the Southern hemisphere strongly influenced the incoming painters whose palette would suddenly brighten and whose interests would turn to landscape painting. This may also be true for the Adelaide cluster of Slav artists. Having experienced the atrocities of the war in their homelands, they would have been eager to express such memories through their work. Indeed, Rapotec's early Australian fully abstract expressionist body of work contained the series Tensions and Disturbances. Another quality of their new Australian environment perhaps contributed to their embracing abstraction - the vastness of the barren land. This is visible in their early Australian works and further developed in their later works.

Would these artists have created the same artworks in Europe, or in some different place? The answer is a categorical no. These artists' presence in Adelaide was unprecedented. Their individual experiences in a foreign barren sunburnt land created a unique response to it. It was the land devoid of direct memories of the atrocities of the war and thus not responsive to their individual life experiences. It was also the unfamiliar environment not aware of their individual cultural memories nor of their common Slav cultural memory. The cluster of Slav émigré artists would have felt an urge to revive their individual and common cultural memories, keep them alive and communicate them to the new environment through their art.

It may not always be possible to argue for a common Slav avant-garde and a Slav idiom in the visual arts history. Because of these artists' initial 
isolation from their new and harsh environment a new Slav avant-garde art idiom was formed in a short period of time. This avant-garde quality of their early Australian works was soon to form part of their individual life experiences and to get articulated in their further individual work.

\section{References}

Bojic, Z. (2005). The Artists of Slav Origins Working in Australia in the Twentieth Century. PhD thesis. Canberra: Australian National University.

Bojic, Z. (2007a). Stanislav Rapotec, a Barbarogenius in Australian Art. Belgrade: Andrejevic Endowment.

Bojic, Z. (2007b). Imaginary Homelands, the Art of Danila Vassilieff. Belgrade: Andrejevic Endowment.

Bungey, D. (2014). John Olsen. Melbourne: Harper Collins Australia.

Burke, J. (2002). Australian Gothic: A Life of Albert Tucker. Sydney: Knopf.

Burke, J. (1983). Joy Hester. Melbourne: Greenhouse Publications.

Casey, B. (2018). The World May Be Large, But It Is Also Round. "Meanjin Quarterly" Winter.

Davidson, I. (1999) Art, Theatre and Photography: Remembering Stan Ostoja-Kotkowski (1922-1994) in Adelaide, South Australia, 1954-1972. Strathalbyn: Davidson.

Dutkiewicz, A. (2000). Raising Ghosts: Post-World War Two European Emigré and Migrant Artists and the Evolution of Abstract Painting in Australia, with Special Reference to Adelaide ca.1950-1965. PhD thesis. Adelaide: University of South Australia.

Dutkiewicz, A. (2006). A Matter of Mind: An Introduction to the Art of Wladyslaw Dutkiewicz (1918-1999). Norwood: Moon Arrow Press.

Edwards, D. (2002) Robert Klippel. Sydney: Art Gallery of New South Wales.

Haese, R. (1981). Rebels and Precursors. The Revolutionary Years of Australian Art. Melbourne: Allen Lane.

Hammond, R. Menadier, B. (2008). From Migrant to Citizen: Artistic Accents. Sydney: Macquarie University.

Heathcote, C. (1995). A Quiet Revolution: The Rise of Australian Art 1946-68. Melbourne: Text Publishing.

Klepac, L. Wach, K. Free, R. James, B. (2004). James Gleeson Beyond the Screen of Sight. Sydney: Beagle Press.

Mould, S. (2008). The Birth of Love: Dušan and Voitre Marek, Artist Brothers in Czechoslovakia and Post-War Australia. Norwood: Moon Arrow Press.

Pearce, B. (2007). Sidney Nolan. Sydney: Art Gallery of New South Wales. 